\title{
HABERMAS' FORMAL PRAGMATICS AND THE SPEECH ACT OF STEPHEN
}

\author{
E Alfred Knight
}

The concept of formal pragmatics exhibits the potential for rationality that is supposed to be implicit in the everyday language practices of societies. It is located in certain idealisations that guide communicative action to the extent that communication is linked to validity. While this reconstructive theory seeks to identify universal presuppositions of everyday communication in modern societies, this paper will show that it can be transposed onto an ancient communication (Stephen's speech) as an example of communicative action. Interpreting Stephen's speech according to Habermas' formal pragmatics in the communicative framework, infers a conception of purpose and potential to build on this example for other speech acts and communicative processes in the Bible. The problem with communicative rationality is that it cannot be reduced to any local context without the risk of it becoming useless for universal application and falling into moral relativism. However, the Bible is full of idealised normative suppositions that can provide standards for justifiable purposive and illocutionary activity. Even though Habermas hopes to provide a post-metaphysical alternative to pre-modern ideals of normativity, it will be shown that the pre-modern biblical text can still be an inspiration for the communicative rationality he sought after. Therefore, the aim of this paper is to analyse the speech act of Stephen in Acts 6:8-7:60 in relation to his formal pragmatics within the context of communicative action, as an example of critical biblical interpretation.

Habermas' formal pragmatics (previously known as 'universal pragmatics') ${ }^{1}$ occupies a central place within the critical endeavour towards a construction of communicative rationality that implicitly validates the base of everyday speech. The introduction of this to the speech motifs found in the book of Acts can give rise to a reading of it that can fit into this framework. In The Theory of Communicative Action (vol. 1, 1984; vol. 2, (1987), Habermas presents a thoroughly systematic work that highlights the theory of language as a course to ground a critical social theory, and move from the critique of ideology to the reconstruction of presuppositions of universal conditions for knowledge and action. This endeavour is referred to by Habermas as 'formal pragmatics' and it can be seen as a semi-transcendental analysis in the Kantian sense that reconstructs the universal pre-theoretical, implicit knowledge that enables practical processes of understanding (Habermas, 1984, 328). It is pragmatic because it focuses on the use of language rather than being empirical, which is concerned with just the description of specific language elements. Therefore, it can be used on speech acts, and these are seen as part of the broader sociological context. While this was intended for everyday communication in modern societies, it can be transposed onto an ancient communication like Stephen's speech as an example of communicative action.

The number of speeches in the book of Acts varies from 24 to 36 depending on how one defines them - from major speeches to mere speech statements. Nevertheless, it is clear that there are an unusually large number of speeches in it, which take up at least 20 percent of the whole book. It means that the Lukan author placed a greater interest on speech material than others of his time, ${ }^{2}$ and this alone makes it an excellent work to undertake an analysis of ancient dialogues in relation to formal pragmatics in the context of communicative action. This paper will focus only on the Stephen speech for practical reasons, although it is hoped that it will encourage 
further research, analysis and theological praxis of biblical discourse using the procedural approach. The speech of Stephen was chosen in particular because it is a good example of New Testament discourse, and it is easily categorised into specific functional stages. Secondly, Stephen - as a Hellenised Jew and chosen leader - was probably familiar with the style of Greek rhetoric, and judging by his speech, well equipped to engage other learned people as a skilled apologist for the gospel (cf. Acts 6:10). Thirdly, he expresses different emotions through the course of his speech, and displays a deep passion for and belief in what he is saying. The paper will begin by introducing Stephen's speech and evaluating the application of Habermas' communicative theory to something biblical. The remainder of the paper will divide the speech into six sections, and each one will be looked at exegetically and then analysed in relation to Habermas' pragmatics. The sections will be as follows: 1 . Acts 6:8-7:1, Stephen's activity that arouses initial opposition; 2. Acts 7:2-8, the patriarchal age; 3. Acts 7:9-19, Israel in Egypt; 4. Acts 7:20-43, the Moses story; 5. Acts 7:44-50, the temple; and 6. Acts 7:51-60, Stephen's personal application and conclusion. There are several issues in this particular biblical passage that could only be examined briefly - the debate over the authorship and authenticity of the speech; the legality of Stephen's trial; the debate over the existence of an anti-temple trend in early Christianity; and whether the execution of Stephen could have been legally sanctioned by the Sanhedrin or if it was an illegal 'lynch-mob' response. These are important and interesting issues, but nevertheless detract from the focus of understanding the narrative function of the speech. The text will be approached exegetically as stated, but for the same reason, it will not be in-depth. Instead, the focus will be on relating the speech to Habermas' theory. Similarly, this paper does not set out to offer an indepth critique of Habermas either; both these approaches would have fallen outside the aim and the scope of this paper and what was trying to be achieved.

One of the premises for Habermas' project of the theory of communicative action is that communicative discourse can be emancipatory, and that forms of discourse have a type of priority over other forms of linguistic usage. His aim is to continue to improve on the dialectic of enlightenment rationality free from the constraints of the philosophies of consciousness. This can be made clearer using Saussure's (1959) distinction between diachronic and synchronic schemata for understanding language. Diachronic follows the model of the enlightenment, understanding language in a historical-evolutionary scheme, while synchronic is an a-historical scheme that isolates language from time, seeing it as a structure of internal relations. Therefore, if language has synchronic elements, it need not be associated with modernity or solely based on an evolutionary model. The historical study of language, for example, can still be approached diachronically, evaluating language evolving in characteristics and complexity - but even in this, it has been discovered that language is universally complex regardless of its place in time; that is, an ancient language can be just as complex as a modern one (Saussure, 1959). Importantly, the discovery of synchronic systems in language presents problems for the diachronic approach in the philosophical study of language and modernity, because the diachronic cannot link its principles to a specific temporally discernable form of linguistic apprehension. As a result, value assumptions often have to be associated with diachronicity when studying language, and this in turn is inconsistent with a modern scientific approach. It does not mean that language cannot be studied diachronically, but the value assumptions associated with it have to be given up. For Habermas, the polemic in modernity is this need to have a certain validity, without forcing it to rely on synchronic schema and avoid the potential error of basing arguments on pre-modern 
theoretical assumptions. It is difficult to determine whether his project is closer to the diachronic model or the synchronic, but it is clear he is attempting to develop a structure of normativity in language that originates out of itself. It is still not clear whether philosophy can do this, as it depends on our conceptions of philosophy, but theological normativity in scriptural language may be able to help.

Ultimately, Habermas' aim is decidedly different. While the aim of this paper is to provide a contributory element for the reading of theology, Habermas' is to provide a basis for a postmetaphysical (modern) concept of reason (Habermas, 1979). To him, religion and theology in the public sphere are positive as the upholder of cultural life, but he argues that moral theory must be post-religious, because religious authority undermines human autonomy (Adams, 2006, pp. 1-4). The public sphere must not remain the territory of one particular kind of tradition because it is there to host all traditions. Be that as it may, the attempt to develop a kind of usefulness from a biblical speech motif will bring with it its own concept of reason that can be extrapolated not only from the text, but also from the theological presuppositions of that particular kind of text, to which the speech of Stephen belongs. Furthermore, as Nicholas Adams points out, Habermas shows no knowledge of post-liberal theology, and his approach fails to do justice to contemporary theology $(2006$, p. 2). However, according to Habermas, all Christians can enter into a moral debate despite denominational or cultural differences because they share a tradition, and all substantive ethical practices have their roots in religious life (Habermas, 1989). If we can reduce any complexity to 'religious life and thought' then a full understanding of post-liberal theology is not necessary.

Habermas' formal pragmatics fulfils the functions of a theoretical underpinning for his theory of communicative action as a critical social theory, and contributes to problems of truth, action and meaning. With this in mind, the issue is how to apply this to a speech in an ancient biblical text when Habermas' intention was its application in the modern sciences. Part of the answer is to use the reconstructed universal competencies that he argues are involved when social actors interact with the aim of achieving mutual understanding. His thesis is based on action aimed at understanding, and this in turn has an in-built connection with validity. As Christians within a shared tradition, the reading of a biblical text pivots on a mutual understanding of the ultimate source of the text, and the validity not only that it comes from God (or at least the acknowledgment that it is regarded as sacred), but the moral imperative not to question this validity. Therefore, Stephen's speech as an example of this contains within it a common social context, a mutual understanding of the Tanakh, and the assumption of validity. While ultimately it was the authority of Jewish tradition that led to his martyrdom, the extreme hostility generated by his speech is an acknowledgment of the authority they shared in the public sphere as a form of communicative action. It is an example where the everyday processes of communication of the day must have presupposed in all parties who were listening and speaking, formal properties of thought, belief and practice, which reconstructed universal competencies that achieved mutual understanding. The speech brought to the fore manifest presuppositions that underlie and guide dialectic exchanges between the speakers and hearers during the process of communication, and from this, universal competencies were reconstructed that led to mutual understanding. The action to achieve this understanding is a type of social action - communicative action. This in turn is connected to an 'in-built' connection with validity, and so it appears to display that the everyday processes in the exchange can be interpreted as claims to validity. 
Habermas draws further distinctions for members of a communication community, where they are meant to have the competency to distinguish between external nature, society and internal nature (Habermas, 1979, p. 67). It is the competence of the speaker relating to these different 'worlds' that enables the adoption of different attitudes, and the communication of the different validity claims of each. In communication directed at society, as in the speech of Stephen, there is an interactive attitude and the raising of a validity claim that offers an evaluation of the rightness of claims governing the relations between social actors. Speech acts are themselves social actions for Habermas, and the speech made by the disciple can be seen as a form of social action whose social use of language was oriented to reaching understanding. It was understanding that focused on the action co-ordinating effects of the validity claims behind the speech act that eventually led to the subsequent lethal actions of the Jewish authorities. Habermas identifies three types of validity claims for understanding: the first is the claim to the truthfulness of what is said (truth), the second is the claim to the normative rightness of the speech act in a given context (rightness), and the third is the genuineness of the speaker (sincerity) (Habermas, 1984). We shall see how this particular speech act meets these claims later, henceforth referred to as truth, rightness and sincerity. The three validity claims are described as universal by Habermas, and are present in every communicative speech act, but with only one claim being highlighted explicitly in a communicative exchange, and the other two being implicit presuppositions of understanding underlying the speech (Habermas, 1979). Therefore, the validity claims of Stephen's speech established intersubjective social relations that made possible the socially-binding recognition of their claims. They were a form of social mechanism for reaching understanding, though instead of building agreement and consensus, they created antagonism, though nevertheless born out of a universal normative connection between the speaker and the recipients. Perhaps the speech may have ended less violently if there had been a rational motivation to accept the claims of the speaker, as the speaker was able to provide grounds and reasons to support his claim. Nevertheless, the resultant action on the part of Jewish authorities from their perspective was still communicative action, because their response was connected to their own communicative rationality to stop a blasphemer and Jewish heretic (though the first validity claim of truth was absent in the members of the synagogue, as the accusations of witnesses were disingenuous). Nevertheless, what underlies the communicative exchange is the reciprocity of the second validity claim of rightness regardless of the subsequent mode of action.

An analytical survey of Stephen's speech act reveals an identity of structure and characteristic variations, which show that older traditions may have been used. ${ }^{3}$ The general schema flows from a direct address particular to the situation, a drawing of attention, a highlighting of scriptural misunderstanding, quotations and proof from scripture, the kerygma of Christ, condemnation, and the proclamation of Jesus as the 'Christ'. It should be noted here that there have been doubts raised about attributing the speeches in Acts to the actual participants; being inventions of the Lukan author. At the forefront of this view were scholars like Martin Dibelius, Ernst Haenchen and Hans Conzelmann, with Dibelius stating:

These speeches, without doubt, are as they stand inventions of the author. For they are too short to have been actually given in this form; they are too similar to one another to have come from different persons; and in their content they 
occasionally reproduce a later standpoint (e.g. what Peter and James say about the Law in chapter xv), (cited in Bruce, 1974, p. 55).

However, while these contributions are significant to the interpretation of the speeches in Luke-Acts, it is immaterial here because we are only concerned with the structure of the speech and its pragmatics as a social tool, regardless of its historical authorship. ${ }^{4}$ Nevertheless, it will be assumed for the sake of consistency and ease, that it was not the invention of the Lukan author (though his style may be present), and that it was a historical figure named 'Stephen' who delivered it. It need not be assumed that the speech is recorded verbatim, and while it may be a composition or condensed account of the speech, it is a suitable and sufficient interplay of the speakers, the hearers, and the circumstances surrounding it to be useful.

Beginning with Acts 6:8-7:1, Stephen's address was aimed at Hellenised Jews who were members of the Synagogue of the Freedmen in Jerusalem, ${ }^{5}$ which comprised people from Cyrene, Alexandria, Cilicia, and Asia (6:9). These were former slaves or children of former slaves who had been emancipated by their owners and given the status of 'freedmen.' A full and formal debate was probably arranged, but it is not indicated what the subject of the debate was to be; though undoubtedly the messiahship of Jesus became the central issue, with Stephen radically explicating this with a passion, using validity claims that included the law of Moses and the temple. It was the very nature of his debate and arguments that brought about the charges laid against him, and the very strength of his reply meant that they 'could not hold their own against the inspired wisdom with which he spoke' (Acts 6:10). It is important to note that the Jewish authorities accepted his premises, that is, the rightness of the authority of the Tanakh, but they could not accept his conclusions; to them they were blasphemous and revolutionary. Their defeat in open debate led to the placement of charges that would particularly anger the people of Jerusalem - a threat to the temple and the Law, and it probably jeopardised the livelihood of the priests also. Stephen was subsequently brought before the Sanhedrin where he gave his speech. The nature of that speech henceforth displays the validity claims of formal pragmatics, and provides an example of biblical application which can be extended to communicative action.

Habermas describes his universals as a continuation and transformation of worldviews, and the problem of religious worldviews is that they are particularist in their own worldview and not universalist (Adams, 2006, p. 92). This does not pose a problem in analysing Stephen's narrative, as we are attempting to seek its application from the particular to a descriptive foreshadow of formal pragmatics, as an example of the everyday linguistic interaction that raised and recognised validity claims. There is a picture of social order in the act, as a network of relationships of mutual recognition that displayed characteristics of cooperative relations of sincerity (implicitly) and responsibility, played out as punishment and religious justice based on the validity claim of rightness (explicitly) in the Tanakh. Chapter seven of Acts marks the beginning of Stephen's speech where the high priest seeks a redress from him, as it was necessary in the Jewish court for the accused to have a right of reply after charges were understood and made clear to them. Here is a procedural framework that in its initial phase provides a validity claim of truth; one which consists of the rights and obligations they believed were necessary in their interactions with each other, as well as the obligations others had in respecting these rights. The status of the high priest's office as the head of the Sanhedrin and chief judge in Israel was derived from birth, and this was symboled by the honour and prestige already accumulated and preserved by his inherit- 
ance. To be an honourable man was the first-century ideal, and he had to fulfil this by living up to his inherited obligations. ${ }^{6}$ Hence, there was a relationship of mutual recognition to begin with - and this is a characteristic of formal pragmatics, to facilitate an inherent rational dimension as part of its truth validity claim - so the high priest had an obligation to act on that truth validity by uttering the declaration, 'Is this so?' - addressed not only to Stephen, but to the whole council and audience as an acknowledgment and honourable obligation to the validity claim. Thus, Acts 7:1 establishes the validity claim of truth for understanding, which is characteristic of communicative action.

The next section of Stephen's address (7:2-8) is about the patriarchal age, and begins a form of 'salvation-history' approach that looks back to ancient events concerning Israel as predictions for the future, made literal through his interpretation of recent events. Stephen's application of the prophetic tradition in his structural pattern and his adaptation of biblical typology, creates a sequence of events so that they are presented in a thematic parallel, reinforcing the argument for legitimacy. The account is concentrated on Abraham's migration, God's promise, the covenant of circumcision, and the birth of Isaac. These are fundamental to the history of ancient Israel, but they have not been given a biblical style, and at several points there are Septuagint phraseologies that are not used in the Judaic Pentateuch story of Abraham (Keck \& Martyn, 1968). The speech alters the biblical account at some points in a substantial manner, not only to match a Hellenised crowd, but as a way to push the posterity of Abraham into the foreground, to provide reasons for the claims of validity he raises in the face of challenge. His counterparts had the onus of providing a better basis of reasons, but these were cut off by the validity of rightness that they both agreed on. Hence, to question the patriarchal narrative was to question the normative context of the sacred scriptures.

The picture of the early disciples of Jesus in the first five chapters of Acts is that they are lawabiding, with none of them going outside the bounds of Judaism. Though the details leading up to the charges laid against Stephen are not clear, we do know that accusations of speaking out against the Law, the temple and the Mosaic customs were made against him. It is difficult to relate Stephen's defence to the charges made against him; as Haenchen points out, he should have been answering to whether he was guilty of the charge, yet the majority of his speech has no bearing on this at all $(1971,286)$. But, if viewed in the context of formal pragmatics, it is not enough to answer the charges in this case with a defence based only on facts. In Habermas' writing on law, such as Between Facts and Norms (1996), even everyday communicative action already involves a rudimentary practice of argumentation, and the fact that these accusations were made by 'false witnesses' (6:13), meant that Stephen could not offer a factual denial, but instead utilises a defence based on law, where even if the alleged accusations were true, they displayed no breach of the law (Esler, 1987, 122-5). It may even be argued that the Jewish council were committing a jurisdictional breach even hearing the case in the first place without due process. In examining Stephen's speech, he does not explicitly rely on this defence, but the manner in which he presents his case constitutes an implicit reliance on it. This is the appeal to universal validity claims of truth and sincerity - not explicitly claimed, but implicitly - as presuppositions of understanding, present in communicative speech. Giving reasons for or against controversial validity claims is viewed as naïve communicative action by Habermas, but Stephen's dialogue of defence highlighted a more sophisticated argumentation that can rightly be described as 'discourse.' In this way, 
communicative action can operate on the assumption that the reasons supporting validity claims are good. As mentioned above, the history of Abraham's posterity was placed in the foreground of his speech, and it is by no chance that the emphasis of biblical story reproduction forms a specific function within the whole speech. That is, it predicts the succeeding events in the history of Israel about the fulfilment of the promise of God to Abraham. It was not necessary at this point to offer any specific Christological or eschatological interpretation of God's promises to Abraham - instead it was communicated as a history of which partial realisations were interconnected with new promises until the coming of Jesus, of whom all the prophets spoke (cf. 7:52).

He follows this up with the next part of his speech concerning ancient Israel in Egypt (7:919). This section highlights the existence of opposition to the purposes of God as early as the patriarchal age, with the sons of Jacob selling Joseph into slavery. It is clear that Stephen is seeing Joseph as a type of Christ, but the typology is subordinated to the recurring pattern of prophecy and fulfilment. This is leading up to a reconstruction of the conditions of possible linguistic communication, where the participants in opposition can raise validity claims in response to Stephen's validity claims, that can be either reciprocally accepted or denied. According to Habermas, a speaker raises a validity claim when the interchange depends on the recipient's ability to respond to the claim with a 'yes' or a 'no' (Habermas, 1979, 63). In raising the validity claim, Stephen is relativising his utterances against the possibility that it will be contested by other agents. Therefore, the existence of the possibility of rejection based on reason, according to formal pragmatics, is giving the speech act validity, and is the defining characteristic of this mode of communication. The very notion of validity implies Habermas' reflective relation to the world that we all appear to have; for to recognise a given speech as a validity claim (as the Jewish council did), the participants must recognise that other participants may have reasons for challenging the speech act's validity also. The relationship is indirect and mediated by a need for intersubjective recognition of the validity claim raised with the speech, and it is this form of pragmatic that leads toward understanding; it does not necessarily lead to agreement but it does achieve intersubjective recognition. A successful communicative action is dependent on the recognition of others as participants who can pursue their aims cooperatively, so that the means of pragmatics is not dependent on any one individual agent. The speech in this case, did not elicit cooperation, which undermined the communicative rationality needed in the pragmatics; this will be addressed later.

The next section of Stephen's speech is the Moses story (7:20-43). This section naturally describes the life of Moses, showing the true extent of his greatness and God's approval. The standards emphasised are beyond human, and this follows the formulation that the Jewish nation has always been rebellious; as previous generations opposed the prophets from Moses onwards. While the form of the speech is for the most part in an established Jewish tradition, it failed to conciliate his accusers and judges, and the manner is often associated with a recital of the divine intervention in the life of Israel - an underlying basis of Rabbinic optimism (Bruce, 1988). Hence, the address at this point is in its true form, but it is in the sequel where he differs from the Hebrew model. The situation emerged where the communicative interaction became problematic when the beliefs and values of Stephen began to surface in the discourse, and it was through this same discourse that the validity claims came into question. The justification of the normative rightness validity claims held their own up until he began his own accusations against the Jewish establishment, claiming discursive vindication in doing so through argumentation. Presenting Moses in 
this light challenged the jurisdiction of the Sanhedrin to have him on trial - since their ancestors rejected Moses and have continued to disobey the law ever since - the Jewish authority had no right to judge Stephen for allegedly speaking against Moses. In other words, there is an irony in the Jews appealing to Moses to condemn him, when they had always disregarded his prediction of a prophet that would come after him (v37). This placed them in a difficult position, where respect for conventional modes of formulative communication that are open-ended and critical, necessitates the conclusion that if the tribunal were to honour their validity claims of truth, rightness, and sincerity in a dialogue about Moses and the law, it would necessitate recognition of the prophet who was promised long ago by him; namely Jesus. Thus, Stephen attempted to dispossess the Jewish council of the Mosaic traditions and reinterpret them in a way that vindicated his own position as a true supporter of Moses, and with the council as the apostates.

This section marks a break from what may be considered normal contexts of social action, to put into place a critically thematised dominant belief system, or what was then a new Christological ideology. An ideal discourse would have involved laying aside all motives except the willingness to reach an agreement free from the constraints of action, and guided by the 'unforced force' of the better argument (Habermas, 1984, 66 ff.). The presuppositions for rational communication are embedded in the structure of speech according to Habermas, but in this case, the normative claims of speech were embedded in the Jewish scriptures, and while the discourse implied a formal pragmatic, there is a reformulation of the normative foundations of the critical theory. That is, the truth claims implied in Stephen's speech and the explicit correctness of the rightness claims to become that of communicative action, depended on a speech act that was free from domination and singular authority within the Judaic religious dynamic. This would have been the 'ideal speech situation,' where the equality of freedom from all forms of constraints for all participants would serve as a critical action, and a standard by which all distorted communication could be measured. The Tanakh reformulated these ideal conceptual relations, and moved from the foundations of rationality to foundations of theological truth. The course of Jewish idolatry is traced from the wilderness and into the Babylonian exile, where Stephen sums up the section by quoting the words of Amos (5:25-27). This is where Jerusalem had given itself over to the celestial worship of planets in the later years of the monarchy, and its placement here implies a continuation or outcome of the earlier idolatry in the wilderness. The Septuagint renderings from which Stephen is quoting are different to the Masoretic text in the names of the star-gods. The name-place to which they were deported, though concurring with the Masoretic text, is changed by him from 'beyond Damascus' to 'beyond Babylon' - probably to make it more relevant to Jerusalem, as the southern kingdom over a century later suffered the same judgment in the Babylonian exile (Prato, 1993; Bruce, 1988). Nevertheless, both forms of the quoted text begin with the rhetorical question, 'Did you bring me sacrifices and offerings during the forty years in the wilderness, O house of Israel?' The implied answer of 'No' would have been understood by Amos as a failure to worship in a true spirit of loyalty or 'heart-worship' instead of perfunctory religious rituals, and by Stephen that Israel did offer sacrifices in the wilderness - but to idols.

The formal pragmatics of this section is similar to that used in the 'patriarchal age' section of his speech, where in its simplest form, the orientation toward understanding is carried out through the speech act. The success of the interaction depended on the hearers responding to the validity claims with an affirmative or a negative, and while Stephen gave support for his claims, 
the accusers never gave reasons for their rejection of it. Habermas believes that every speech act, by virtue of the validity claims it raises, enters the speaker and hearer into an interpersonal relationship of mutual obligation, whereby the speaker is obligated to support claims with reasons if challenged, and the hearer is obligated to accept the claims unless there are good reasons not to do so (Habermas, 1996, 395). This obligation appears to be more a moral one than a rational one, and while Habermas would probably describe it as irrationality rather than immorality, there is no doubt that Stephen was invoking a moral conviction through his historical narrative and interpretation (cf. 7:54). He attempted to situate Christianity, through Moses, firmly within the ancestral traditions of the Jewish people, so that the ancestral history became 'salvation history,' and the foundation for believing in Jesus. So, there is an internal connection between action and process that provides good reasons for parties in the particular (Jewish) society, to either accept or reject that these validity claims may be regarded as reasonable or even beyond dispute. The ultimate reaction to his speech made obvious their decision to reject, though it is interesting to note that there was no real attempt to give good reasons for it.

The next section of Stephen's speech concerns the temple (7:44-50), and is a response to one of the charges made against him. His remarks, particularly in verse 47: 'But it was Solomon who built a house for him', followed by 'yet the Most High does not dwell in houses made with hands' (v48), has been taken to imply a radical opposition against the temple. ${ }^{7}$ However, a closer reading of the historical narrative shows this to be inconsistent with the theme of his speech. He begins this section stating that the tent of testimony was made according to a spiritual or heavenly model, accompanied the Jews in the wilderness and was brought into the Promised Land under Joshua. It remained in this state and practice until the days of David, when he found favour in the sight of God and sought to provide a permanent habitation for the God (or house) ${ }^{8}$ of Jacob. That is, the fulfilment of God's promise to Abraham was on the verge of being completed through David, though it was Solomon who built the 'house for him.' Therefore, at this point in the speech, Stephen gives the impression that the promise would appear to have been realised through the temple of Solomon - but this is not so - for 'the Most High does not dwell in houses...' (v48). Even though Solomon had built a house for him, Stephen would not have quoted Isaiah 66:1,2 if it were the completion of God's covenant. It is here that early Christology influences Stephen's interpretation of promises made to Abraham - for now it is implied that the uncompleted 'tent of David' has been 're-erected' and completed in Jesus (cf. Acts 15:16, 17; Luke 1:32,33) - thus it is not a physical dwelling. Therefore, rather than opposing the temple and its practices, Stephen is proactively representing himself as an example of true worship of God in Jerusalem, whether in the temple or in private homes, now in the name of Jesus.

At this point, it appears that the background consensus was disrupted (though the normative claims remained intact), which is usually a characteristic of post-traditional societies where communicative action does not happen as routinely as in traditional societies. Habermas acknowledges that some cultures are more able to 'decentre' themselves and take up a more critical attitude toward their traditions, conceptions and identity (Habermas, 1984, 66 ff.). While this may have been characteristic of a Hellenised Jewish culture, the connection between the everyday language practices of argumentation and communicative action was broken. When this happens, Habermas implies that the participants have a few options; they can switch to strategic action; they can sever communication; or they can continue the communicative activity at a more reflective level, 
which he calls argumentative speech (Habermas, 1979, 65-6). In the lines of Stephen's speech that follow till the end, the presuppositions are unavoidably confirmed in the practice of his reflective argumentation, and he boldly carries it through to its outcome. For whatever else contributed to the eventual stoning of Stephen, the Sanhedrin and the Jews around him were faced with the idealised suppositions that he raised explicitly and implicitly. These gave meaning to the ideas of truth and justice as validity claims that transcended their local contexts of validity. To this extent, it led to an act of violent retribution, because they were unavoidably aware of their validity claims in consensus with Stephen, but chose to sever communication anyway, and not reciprocate his reflective speech action (see v57). Had they not done so, the processes of communication could have connected with reflective argumentation, and created a possible vindication in discourse that called on scripture as their context-transcendent vehicle, and drew on the rational potential built into the processes of everyday communication.

This led to the final section of Stephen's speech, which was the personal application of his historical narrative and conclusion (7:51-60). He confronts the Jews of Jerusalem with a climactic indictment after using their own sacred history; a history according to Stephen, of constant disobedience and opposition to God and his prophets, all the while building up rage in his listeners. Therefore, it should not be assumed that the violent response of the audience was caused only by what Stephen says from this point onward. He has used the scriptures to formulate his point of view, and now takes it a step further, contending that their betrayal and murder of Jesus has created a commonality between themselves and the contemporaries of Moses and the persecutors of the prophets. Against this resistance to the Holy Spirit stands a succession of righteous sufferers all through to Jesus, and now to Stephen as well, also full of the Holy Spirit (v55). There is the implied conclusion that along this line of persecution, the covenants and divine promises of God are brought to fulfilment in Jesus, and those who reject Jesus therefore, are disinheriting themselves from God's promise to the descendents of Abraham. The speech builds to a dramatic conclusion after relating the stubbornness of Israel, and is significant to the preaching of the 'good news' at this stage, because it affirms the rightful claims of Jesus as the 'Christ' who is resurrected and exalted at the right hand of God. Thus, the historical narrative and communicative function served to provide a reflexive proof that Jesus had been raised up as 'Lord', and is therefore, the messiah of Israel as claimed by the apostles. It also provided the momentum for the expansion of the message beyond Jerusalem, as it heralded the beginning of an immediate campaign of intense persecution that dispersed the Jerusalem church and forced its followers into outer regions where they spread the Christian message. There is debate whether Stephen's execution was sanctioned by the Sanhedrin, or if it was more a 'lynch-mob' response to his speech. While there was no formal verdict offered by the high priest, no formal sentencing announced, and the stoning carried out spontaneously, it is clear that the crowd thought that Stephen was blaspheming something, and stoning was the appropriate penalty for this. However, Klausner points out that according to Talmudic rule, ${ }^{9}$ the blasphemer is not culpable unless he pronounces the Name itself - which Stephen did not (cited in Bruce, 1988, 158); but Bruce notes that the restriction of blasphemy to the actual pronouncement of the ineffable name was a later rabbinical refinement $(1988$, ibid.). There was the required presence of witnesses to throw the first stones according to law, ${ }^{10}$ as well as the practice of removing their outer garments to do so. However, does the spontaneity of the execution call into question its legality - as a legal execution could not be carried out without 
Roman authorisation which would have taken time? Bruce notes that the charge of 'speaking against the temple,' probably belonged to the category of offences against the temple in relation to which the Roman administration, as an exception, gave permission to the Jewish authorities to carry out death sentences without reference to the governor (1988, 159). Nevertheless, whether this was an act of Jewish paranomia or not, depends on finding a concrete link between charge and sentence, which is ambiguous based on this account.

If one were to view Habermas' formal pragmatics working in a network of cooperation within a given social order, then it comes as no surprise that the outcomes of Stephen's speech played out in such a manner. The cooperation requires commitment and responsibility between strategically acting subjects as a fundamental groundwork to apply conceptions of contexttranscendent validity claims as purposive activities. The speech act is described by Habermas as a reflexive self-interpretation that has the goal of reaching understanding, and corresponding to that goal is a value laden state in the world that is brought into existence through the choice and application of apparently appropriate means (Habermas, 1988, 3-4). Stephen's speech act was a means to reach understanding, and the hearers understood the meanings of what was being said, but the acknowledgment or more accurately, the acceptance of the validity claims were not acted on. The last section of the account displayed three characteristics that prevented the acceptance of claims: firstly, the goals of both parties - speakers and hearers, were defined independently of the linguistic means for reaching understanding. Natural language requires interpretation reciprocally to reach understanding, and mere independent utterances do not constitute means for reaching this goal. Secondly, the illocutionary success of Stephen's speech depended on the hearer's rationally motivated agreement. The Jewish audience and council did not willingly give approval to agreement on the subjects at hand by openly recognising the validity of the validity claims. Finally, the most important; the process of communication from the perspective of the participants did not constitute inner-worldly states. The speaker and hearer remained as sole entities in the world during the speech act, and this made them objects in opposition. What was required from the speaker and hearer was to adopt a performative attitude where they encountered one another as members of an intersubjectively shared life-world of their linguistic community (Habermas, 1988, ibid.). In other words, though they reached an implicit and explicit agreement of the validity claims, in order to reach understanding with each other, they had to recognise themselves with the other person as players in a world whose (illocutionary) aims that are pursued, reside beyond the external world of purposive activity (to which the Sanhedrin and the crowd based their decisions). So, while the speech act began with the potential for communicative action, it lingered in what Habermas describes as a 'transmundane' state (1988, ibid.). Stephen's speech act was a self-interpreting action with a reflexive structure that was directed toward illocutionary goals, but failed to achieve its purpose of changing the hearers introspectively, and was not open to the rational cooperation (inherent in the words themselves) necessary for reaching understanding.

\section{CONCLUSION}

Having reached the end of Stephen's speech in Acts, interpreting it according to Habermas' formal pragmatics in the communicative action framework, infers a conception of purpose and potential to build on this example for other speech acts and communicative processes in the 
Bible. The New Testament especially abounds with speeches, dialogues and third-person quotes that can be situated in daily life; with theological normative concepts of truth, hope, faith, love, forgiveness, and so on; forming the foundations in idealising suppositions of everyday purposive and illocutionary activity. The biblical text can provide the inspiration for the communicative rationality sought after by Habermas, needed for communicative action, which cannot be reduced to any local context for risk of it becoming useless for universal application, and falling into moral relativism. Hence, suppositions need to be idealised to provide standards for critique, justification or acceptance. While he hopes to provide a post-metaphysical alternative to the premodern ideals of normativity, the pre-modern biblical text can be an exception.

\section{ENDNOTES}

His original term was 'universal pragmatics'. Though it was not made absolutely clear, Habermas was probably attempting to weaken his interpretation of the transcendental, compared to Kant. In a footnote to his essay 'What is Universal Pragmatics?' he stated that the term formal pragmatics' as an extension of formal semantics would serve better. (Habermas, 1979, n. 1).

For example, Josephus devotes less than $9 \%$ of his Jewish Wars to speeches.

3 For a more comprehensive study of this, see Denova (1997).

For counter-arguments to this view see authors such as S. J. Kistemaker (1990); A. F. J. Klijn (1957); and F. F. Bruce (1974).

A Hellenised synagogue in Jerusalem that pre-dates $70 \mathrm{CE}$ is identified from a Greek inscription set up by its founder Theodotus, and it is considered to be the synagogue referred to here by Luke; see Deissmann (1927): 439-441.

6 For an in-depth study of the cultural anthropology of first-century Palestine, see Malina (1981). The notion that the temple is the place where God resides on earth was deeply implanted in the Jewish religion; for more insight into this notion see Esler (1987): 131-161 On whether this should be rendered 'house' or 'God' see Simon (1958).

See Mishnah, Sanhedrin 7:5.

10 For details of the formal procedure for execution by stoning under Jewish law, see Mishnah, Sanhedrin $6: 1-4$.

\section{REFERENCES}

Adams, N. 2006. Habermas and Theology. Cambridge: Cambridge University Press.

Bruce, F. F. 1974. The speeches in Acts - thirty years after. In Banks, R. (ed.) Reconciliation and Hope: New Testament Essays on Atonement and Eschatology Presented to L.L. Morris on his 60th Birthday.

Carlisle: Paternoster.

Bruce, F. F. 1988. The Book of the Acts. (Revised). Michigan: Eerdmans.

Conzelmann, H. 1982. The Theology of St Luke. Trans. G. Buswell. Philadelphia: Fortress.

Deissmann, A. 1927. Light from the Ancient East. (pp. 439-41) London: Hendrickson Publishers

Denova, R. I. 1997. The Things Accomplished Among Us: Prophetic Tradition in the Structural Pattern of Luke-Acts. Great Britain: Sheffield Academic Press.

Esler, P. F. 1987. Community and Gospel in Luke-Acts. Cambridge: Cambridge University Press Habermas, J. 1979. What is universal pragmatics? In: Habermas J. Communication and the Evolution of Society. Trans. T. McCarthy. London: Heinemann. 
Habermas, J. 1984/1987. The Theory of Communicative Action. Two volumes. Trans. T. McCarthy. Boston: Beacon.

Habermas, J. 1988. Actions, speech acts, linguistically mediated interactions, and the Lifeworld. In Fløistad G (ed.) 1994. Philosophical Problems Today. Dordrecht: Kluwer.

Habermas, J. 1989. The Structural Transformation of the Public Sphere. Trans. T. Burger. Cambridge: Polity. Habermas, J. 1996. Between Facts and Norms. Trans. W. Rehg. Cambridge: Polity.

Haenchen, E. 1971. The Acts of the Apostles: A Commentary. Westminster: John Knox.

Keck, L. E.; Martyn, J. L. 1968. Studies in Luke-Acts. Great Britain: Abingdon.

Killgallen, J. J. 1993. Persecution in the Acts of the Apostles. In G. O’Collins \& G. Marconi (eds.). Luke and Acts, New Jersey: Paulist.

Kistemaker, S. J. 1990. The speeches in Acts. Criswell Theological Review 5(1): 31-41.

Klijn, A. F. J. 1957. Stephen's speech - Acts VII. 2-53. New Testament Studies 4: 25-31.

Malina, B. J. 1981. The New Testament World: Insights from Cultural Anthropology. Atlanta: John Knox.

Prato, G. L. (993. Idolatry compelled to search for its gods: A peculiar agreement between textual tradition and exegesis (Amos 5:25-27 and Acts 7:42-43). In O’Collins, G. \& Marconi, G. (eds.). Luke and Acts. New Jersey: Paulist.

Rehg, W. 1994. Insight and Solidarity: A Study of the Discourse Ethics of Jürgen Habermas. London: University of California Press.

Roderick, R. 1986. Habermas and the Foundations of Critical Theory. New York: St Martin's.

Saussure de, F. 1959. Course in General Linguistics. New York: McGraw-Hill.

Simon, M. 1958. Saint Stephen and the Hellenists in the Primitive Church. London: Longmans.

Cite this article as: E Alfred Knight. 2010. 'Habermas' formal pragmatics and the speech act of Stephen'. The Bible and Critical Theory6 (1): pp. 4.1-4.13. DOI: 10.2104/bc100004. 